\title{
ANALISIS CLUSTERING VIRUS MERS-CoV MENGGUNAKAN METODE SPECTRAL CLUSTERING DAN ALGORITMA K-MEANS
}

\author{
Septian Wulandari ${ }^{1}$, Dian Novita ${ }^{2}$ \\ Program Teknik Studi Informatika, Universitas Indraprasta PGRI \\ septian.pmb09@rocketmail.com ${ }^{1}$, dyan.novita@gmail.com ${ }^{2}$
}

Submitted November 16, 2020; Revised March 27, 2021; Accepted March 28, 2021

\begin{abstract}
Abstrak
Virus MERS-Cov telah menyebar hingga ke negara-negara lain di luar Arab Saudi. Hal ini dikarenakan virus MERS-CoV dapat bermutasi dengan cepat sehingga dikhawatirkan dapat mengancam kesehatan masyarakat bahkan kesehatan dunia. Virus ini berkembang dan menjadi penyakit pernapasan akut serta angka kematian mencapai 30\% di antara 536 kasus. Salah satu cara untuk mengelompokkan virus MERS-CoV adalah dengan mengelompokkan susunan DNA pada virus MERS-CoV yang memiliki kesamaan sifat dan fungsinya. Spectral clustering merupakan salah satu metode pengelompokkan yang dapat mengidentifikasikan ekspresi gen DNA. Metode ini juga mampu mempartisi data DNA dengan struktur yang lebih rumit dibandingkan dengan metode partisi clustering. Tujuan dari penelitian ini adalah menganalisis clustering virus MERS-CoV menggunakan metode spectral clustering dan algoritma $k$-means.Penelitian ini menggunakan pendekatan literature deskriptif kuantitatif. Hasil penelitian menunjukkan bahwa hasil clustering dengan metode spectral clustering dan algoritma $k$-means dihasilakan tiga cluster dan lebih homogen dibandingkan dengan clustering hanya menggunakan $k$-means saja.
\end{abstract}

Kata Kunci : K-Means, Spectral Clustering, Virus Mers-CoV

\begin{abstract}
The MERS-Cov virus has spread to other countries outside Saudi Arabia. This is because the MERSCoV virus can mutate rapidly so it is feared that it could threaten public health and even world health. This virus develops and becomes an acute respiratory disease and the mortality rate reaches $30 \%$ among 536 cases. One way to classify the MERS-CoV virus is by grouping the DNA sequences of the MERS-CoV virus which have similar characteristics and functions. Spectral clustering is a grouping method that can identify DNA gene expression. This method is also able to partition DNA data with a more complex structure than the partition clustering method. The purpose of this study was to analyze the MERS-CoV virus clustering using the spectral clustering method and the k-means algorithm. This study used a quantitative descriptive literature approach. The results showed that the results of clustering using the spectral clustering method and the k-means algorithm produced three clusters and were more homogeneous than clustering using $k$-means only.
\end{abstract}

Key Words : K-Means, Spectral Clustering, Mers-CoV Virus

\section{PENDAHULUAN}

Middle East Respiratory Syndrome (MERS) adalah suatu penyakit pada saluran pernapasan yang disebabkan karena virus corona jenis baru dan disingkat dengan nama MERS-CoV. MERS-CoV pertama kali ditemukan di negara Arab Saudi pada tahun 2012. Virus ini berkembang dan menjadi penyakit pernapasan akut serta angka kematian mencapai $30 \%$ di antara 536 kasus yang dilaporkan pada 12 Mei 2014 [1]. Pada sejak April 2012 hingga akhir November 2019, terdapat total 2494 kasus sindrom pernapasan Timur Tengah (MERS) yang dikonfirmasi pada laboratorium, termasuk 858 kematian terkait (dengan kasus tingkat kematian: 34,4\%) [2]. 
Virus MERS-Cov telah menyebar hingga ke negara-negara lain di luar Arab Saudi. Hal ini dikarenakan virus MERS-CoV dapat bermutasi dengan cepat sehingga dikhawatirkan dapat mengancam kesehatan masyarakat bahkan kesehatan dunia. Virus MERS-CoV merupakan spesies beta coronavirus yang dapat menginfeksi manusia. Struktur genom pada virus MERS-CoV mengandung dipeptilpeptidase 4 (DPP4, atau CD26) yang diidentifikasikan sebagai reseptor host-sel untuk entry sel [1]. Karakteristik struktur genom pada virus MERS-CoV dapat diketahui dengan mengidentifikasikan susunan nukleotida pada DNA. Deoxyribonucleic acid (DNA) merupakan polinukleotida untai ganda yang memiliki karakteristik komponen penyusun antara lain gula deoksiribosa, gugus fosfat dan basa nitrogen (adenin, guanin, timin dan sitosin) [3]. Perbedaan penyusunan keempat nukleotida itulah yang menjadi perbedaan karakteristik pada semua makhluk hidup.

Sejak tahun 2012 orang yang terjangkit virus MERS-CoV tidak hanya ditemukan di negara Arab Saudi, namun virus ini telah mewabah ke berbagai negara di luar Arab Saudi seperti Jerman, Yunani, Prancis, Italia, Belanda, Inggris (UK), Mesir, Malaysia, Filipina, dan Tunisia [4]. Oleh karena itu, perlu dilakukan penelitian terhadap virus MERS-CoV mengelompokkan penyebaran virus MERS-CoV serta untuk meminimalisir penyebarannya ke negara lain dan mencegah penularannya kepada turis asing yang berkunjung ke negara-negara yang terpapar virus MERS-CoV.

Salah satu cara untuk mengelompokkan virus MERS-CoV adalah dengan mengelompokkan susunan DNA pada virus MERS-CoV yang memiliki kesamaan sifat dan fungsinya. Spectral clustering merupakan salah satu metode pengelompokkan yang dapat mengidentifikasikan ekspresi gen DNA. Jika matriks kesamaan pada ekspresi gen DNA yang dibangun dapat mendekati matriks ideal, metode spectral clustering akan memiliki kinerja pengelompokan yang lebih baik [5]. Disamping itu spectral clustering juga merupakan salah satu metode clustering yang pernah dikembangkan dalam memperbaiki akurasi regresi [6].

Penelitian terdahulu yang menggunakan analisis clustering pada DNA virus MERSCoV dilakukan oleh Alhadi Bustamam, et, all pada tahun 2017 dengan menggunakan metode k-mer [4]. Pada penelitian tersebut digunakan 20 urutan DNA MERS-CoV dan memiliki hasil untuk beberapa penderita MERS-CoV yang berasal dari suatu negara belum tentu terinfeksi dari negara asal yang sama. Sedangkan, penelitian yang dilakukan oleh A. Chin, et, all pada tahun 2015 dengan melakukan spectral clustering pada ekspresi gen untuk mengidentifikasi jenis atau subjenis kanker menghasilkan sebelas data ekspresi gen pada spectral clustering mengungguli keenam metode clustering lainnya [7]. Pada metode spectral clustering, algoritma partisi yang umumnya digunakan adalah menggunakan algoritma k-means. Algoritma $K$-Means clustering merupakan algoritma yang berperan penting dalam bidang data mining serta sederhana untuk diimplementasikan dan dijalankan [8]. Sehingga metode spectral clustering diharapkan mampu mengelompokkan susunan DNA pada virus MERS-CoV.

Tujuan dari penelitian ini adalah menganalisis clustering virus MERS-CoV menggunakan metode spectral clustering dan algoritma $k$-means. Pada penelitian ini diharapkan mampu memberikan informasi penyebaran virus MERS-CoV melalui kesamaan karakteristik DNA virus MERS$\mathrm{CoV}$ di berbagai negara yang terjangkit. 


\section{METODE PENELITIAN}

Pada penelitian ini digunakan pendekatan studi literatur deskriptif kuantitatif. Pendekatan studi literatur dengan mengumpulkan referensi uantuk mendukung penyelesaian penelitian ini. Kemudian, pendekatan deskriptif kuantitatif dilakukan dengan mengolah, menganalisa, dan menginterpretasikan data sesuai dengan kebutuhan peneliti.

Data yang digunakan pada penelitian ini adalah 100 data barisan DNA virus MERS$\mathrm{CoV}$ yang didapatkan dari National Center for Biotechnology Information (NCBI) pada website www.ncbi.nlm.nih.gov. Data barisan DNA virus MERS-CoV yang diperoleh berupa format FASTA. Barisan DNA yang digunakan berjenis complete genome, karena berjenis complete genome diharapkan data tersebut mampu memberikan informasi genetik virus MERS-CoV yang lebih banyak. Data yang digunakan pada penelitian ini masih berbentuk string atau barisan DNA Virus MERS-CoV. Dikarenakan data yang digunakan masih dalam bentuk string, maka data tersebut perlu diubah menjadi bentuk numerik. Tahap pertama yang dilakukan pada penelitian ini adalah mengubah data dalam bentuk string menjadi numerik dilakukan dengan ekstraksi ciri menggunakan n-mers frequency. $N$-mers frequency atau $k$-mers frequency merupakan perhitungan frekuensi dari panjang string yang diberikan pada proses membaca kumpulan barisan [9]. The number of features for any sequence DNA is thus the total number of possible k-mers [8]. Hal ini menunjukkan bahwa k-mers merupakan jumlah ekstraksi ciri yang mungkin untuk setiap urutan barisan DNA.

Nilai yang diperoleh dari ekstraksi ciri sangat bervariasi mulai dari data yang terlalu besar sampai dengan data yang terlalu kecil, sehingga perlu adanya normalisasi atau standarisasi untuk menyeragamkan interval pada data. Tahap kedua yang dilakukan pada penelitian ini adalah normalisasi data dengan menggunakan min-max normalization. Berikut merupakan rumus min-max normalization [10]:

$$
v^{\prime}=\frac{v-\min }{\text { max }-\min }\left(n e w_{\text {max }}-n e w_{\text {min }}\right)+n e w_{\text {min }}
$$

Keterangan: $v$ : nilai elemen hasil ekstraksi n-mers frequency sebelum dinormalisasi

$v^{\prime}$ : nilai elemen hasil ekstraksi n-mers frequency setelah dinormalisasi

$\min$ : nilai minimum matriks max: nilai maksimum matriks new $w_{\max }$ : nilai range maksimum terbaru

$n e w_{\text {min }}$ : nilai range minimum terbaru

Setelah dilakukan normalisasi, maka langkah ketiga yang dilakukan adalah proses clustering dengan menggunakan metode spectral clustering dengan menggunakan algoritma k-means. Spectral clustering merupakan salah satu metode pengelompokkan yang mudah digunakan dan metode pengelompokkan yang cukup cepat, terutama untuk data yang renggang hingga data beberapa ribu.

Dalam metode spectral clustering memperlakukan pengelompokan data sebagai grafik dan mempartisi data tanpa membuat asumsi dalam bentuk cluster data. Spectral Clustering akan dibentuk sebuah graf dari data yang ada. Dimana verteks dari graf tersebut merupakan setiap record pada data. Edge-nya berupa hubungan antar data yang biasanya bernilai jarak dari dua record yang berhubungan [6].

Langkah-langkah dalam spectral clustering yaitu [6]:

1. Kontruksi graf similaritas dari dataset training. Verteks pada graf tersebut merupakan representasi dari setiap 
record pada data training. Bobot dari tiap edge merupakan jarak antara satu verteks dengan verteks lainnya. Perhitungan jarak antar verteks menggunakan persamaan jarak exponential yang tertulis pada persamaan 2.

$$
w_{i j}=\exp \frac{-\left\|s_{i}-s_{j}\right\|^{2}}{2 \sigma^{2}}
$$

Setelah itu, bobot dari setiap edge yang ada dibentuk menjadi matriks weight. Dengan begitu matriks weight merupakan representasi graf similaritas dari dataset.

2. Dari matriks weight dihitung derajat dari setiap verteks dengan menjumlahkan bobot dari edge yang terhubung pada verteks yang bersangkutan. Dari derajat verteks tersebut dapat dibentuk matriks degree yang merupakan matriks diagonal yang berisi bobot setiap verteks.

3. Dibentuk normalisasi matriks Laplacian dengan menggunakan matriks weight $(W)$ dan matriks degree $(D)$ yang telah dihitung sebelumnya. Perhitungan matriks Laplacian $(L)$ dengan rumus pada persamaan (3).

$$
L=D-W
$$

4. Dihitung $\mathrm{k}$ eigenvector pertama dari matriks Laplacian, dimana $k$ merupakan parameter jumlah cluster. Maka terbentuklah matriks k-eigen yang merupakan $k$ eigenvector pertama dari matriks Laplacian. Matriks k-eigen berukuran $n x k$, dengan variabel $n$ merupakan jumlah record pada data masukan.

5. Normalisasi data dengan matriks $k$ eigen sehingga akan terbentuk $k$ kolom yang merepresentasikan setiap nilai normalisasi eigen pada setiap kolomnya.

6. Hasil dari data normalisasi kemudian di cluster dengan menggunakan algoritma partisi $k$-means. Data normalisasi mewakili masukan data latih. Data latih ke- $i$ akan dimasukkan pada suatu cluster jika dan hanya jika data hasil normalisasi ke- $i$ masuk pada cluster yang sama.

Berikut merupakan diagram alur pada penelitian ini:

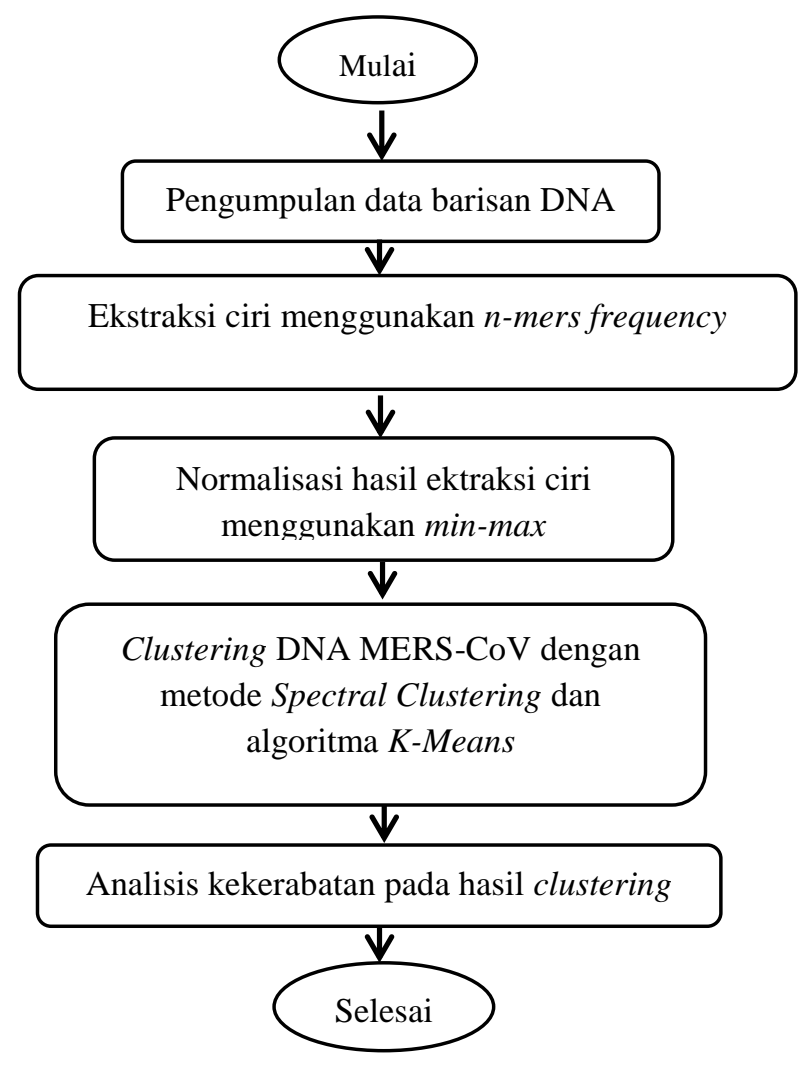

Gambar 1. Diagram Alur Penelitian

\section{HASIL DAN PEMBAHASAN}

Pengumpulan data pada penelitian ini diambil pada laman NCBI yaitu 100 barisan DNA Virus MERS-CoV dengan format FASTA atau string. Kemudian analisis clustering virus MERS-CoV menggunakan metode spectral clustering dan algoritma $k$-means dilakukan dengan langkah-langkah sebagai berikut:

1. Langkah pertama yang dilakukan adalah mengubah data dalam bentuk string menjadi numerik dilakukan dengan 
ekstraksi ciri menggunakan n-mers frequency.

\begin{tabular}{|l|l|l|l|l|l|l|l|l|}
\hline 1 & atg & att & caa & cac & cag & cat & cca \\
\hline 2 & 721 & 744 & 567 & 426 & 421 & 498 & 383 \\
\hline 3 & 721 & 744 & 567 & 426 & 421 & 498 & 383 \\
\hline 4 & 700 & 730 & 560 & 427 & 420 & 472 & 377 \\
\hline 5 & 700 & 730 & 560 & 427 & 420 & 472 & 377 \\
\hline 6 & 701 & 728 & 560 & 427 & 419 & 472 & 377 \\
\hline 7 & 703 & 729 & 560 & 426 & 420 & 473 & 377 \\
\hline 8 & 701 & 726 & 561 & 427 & 420 & 471 & 378 \\
\hline 9 & 700 & 727 & 561 & 426 & 419 & 472 & 377 \\
\hline 10 & 702 & 727 & 561 & 426 & 420 & 472 & 378 \\
\hline 11 & 700 & 729 & 560 & 427 & 419 & 471 & 377 \\
\hline 12 & 697 & 729 & 554 & 424 & 414 & 477 & 371 \\
\hline 13 & 706 & 737 & 562 & 428 & 416 & 479 & 374 \\
\hline 14 & 704 & 735 & 565 & 421 & 421 & 483 & 375 \\
\hline 15 & 699 & 723 & 558 & 417 & 417 & 478 & 371 \\
\hline 16 & 702 & 726 & 560 & 418 & 418 & 473 & 371 \\
\hline 17 & 722 & 751 & 568 & 421 & 420 & 499 & 383 \\
\hline
\end{tabular}

\section{Gambar 2. Potongan Ekstraksi Ciri Barisan} DNA MERS-CoV

Gambar 2 menunjukkan potongan ekstraksi ciri 100 barisan DNA MERS$\mathrm{CoV}$ yang diperoleh dengan pola kemunculan empat basa yaitu kombinasi A, C, G, T dan protein memiliki tiga basa sehingga pola kemunculan menjadi adalah $4^{3}=64$ kombinasi kemunculan protein atau asam amino yang menjadi variable pada penelitian ini.

2. Langkah kedua adalah melakukan normalisasi dari hasil ekstraksi ciri untuk membuat rentang data menjadi 0 sampai dengan 1 digunakan rumus min max normalization pada persamaan (1) dan diperoleh hasil pada Gambar 3. Pada Gambar 3 terlihat bahwa hasul ekstraksi ciri yang memiliki rentang nilai yang berjauhan menjadi normal setelah dilakukan normalisasi sehingga rentang data barisan DNA MERS-CoV berada pada 0 sampai dengan 1 .

ace acg act aga agc agg $\begin{array}{llllllllllll}0,3927765 & 0,2234763 & 0,7155756 & 0,4909707 & 0,3848758 & 0,3961625\end{array}$ $0,63882620,39277550,22347630,71557560,49097070,3848758$ $0,62528220,38713320,22573360,70541760,48081260,3837472$ $\begin{array}{lllllll}0,6252822 & 0,3871332 & 0,2257336 & 0,7054176 & 0,4808126 & 0,3837472\end{array}$ $\begin{array}{lllllll}0,6241535 & 0,3882619 & 0,2257336 & 0,7054176 & 0,479684 & 0,3837472\end{array}$ $\begin{array}{llllllll}0,6241535 & 0,3882619 & 0,2257336 & 0,7031603 & 0,4819413 & 0,3837472\end{array}$ $\begin{array}{lllllll}0,6241535 & 0,3882619 & 0,2257336 & 0,7054176 & 0,4808126 & 0,3837472\end{array}$ $\begin{array}{llllllll}0,6241535 & 0,3882619 & 0,2257336 & 0,7054176 & 0,4785553 & 0,3837472\end{array}$ $\begin{array}{llllllll}0,6241535 & 0,3882619 & 0,2257336 & 0,7054176 & 0,4808126 & 0,3837472\end{array}$ $\begin{array}{lllllllll}0,6241535 & 0,3871332 & 0,2257336 & 0,7076749 & 0,4808126 & 0,3837472\end{array}$ $\begin{array}{lllllll}0,6320542 & 0,3860045 & 0,2223476 & 0,7009029 & 0,479684 & 0,3803612\end{array}$ $\begin{array}{llllllll}0,6286682 & 0,3893905 & 0,2268623 & 0,7121896 & 0,4887133 & 0,3848758\end{array}$ $\begin{array}{llllllll}0,6264108 & 0,3882619 & 0,227991 & 0,7121896 & 0,4887133 & 0,3860045\end{array}$ $\begin{array}{llllllll}0,6207675 & 0,3837472 & 0,2268623 & 0,7088036 & 0,4774266 & 0,3814898\end{array}$ $\begin{array}{llllllll}0,6218962 & 0,3848758 & 0,2268623 & 0,7076749 & 0,4785553 & 0,3826185\end{array}$

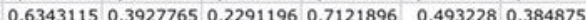

$0,63431150,39051920,22911960,71218960,49209930,3848758$

Gambar 3. Potongan Normalisasi Barisan DNA MERS-CoV
3. Langkah ketiga adalah proses clustering dengan menggunakan metode spectral clustering dan algoritma $k$-means. Proses clustering dilakukan dengan mengkonstruksi graf similaritas dari dataset training. jika dua titik berdekatan maka $s_{i j}=1$ dan ketika dua titik berjauhan maka $s_{i j}=0$. Sehingga ketika dua titik berasal dari cluster yang berbeda maka dua barisan DNA MERS-CoV memiliki jarak yang jauh. Namun, mungkin juga terdapat dua titik dari cluster yang sama juga memilki jarak yang jauh, kecuali terdapat urutan titik dari cluster yang sama yang membuat jalur diantara keduanya. Sehingga matriks $\mathrm{S}$ diperoleh hasil pada Gambar 4.

$[, 1] \quad[, 2] \quad[, 3]$

$[1] ,1.000000 \mathrm{e}+00 \quad 3.659504 \mathrm{e}-01 \quad 1.349792 \mathrm{e}-01$

$[2] ,3.659504 \mathrm{e}-01 \quad 1.000000 \mathrm{e}+00 \quad 3.678792 \mathrm{e}-01$

$[3] \quad ,1.349792 \mathrm{e}-01 \quad 3.678792 \mathrm{e}-01 \quad 1.000000 \mathrm{e}+00$

$[4] \quad ,4.969783 \mathrm{e}-02 \quad 1.353319 \mathrm{e}-01 \quad 3.678619 \mathrm{e}-01$

$[5] \quad ,1.829207 \mathrm{e}-02 \quad 4.978619 \mathrm{e}-02 \quad 1.353319 \mathrm{e}-01$

$[6] \quad ,6.730480 \mathrm{e}-03 \quad 1.831527 \mathrm{e}-02 \quad 4.978580 \mathrm{e}-02$

$[7] \quad ,2.476474 \mathrm{e}-03 \quad 6.737815 \mathrm{e}-03 \quad 1.831522 \mathrm{e}-02$

$[8] \quad ,9.111811 \mathrm{e}-04 \quad 2.478709 \mathrm{e}-03 \quad 6.737816 \mathrm{e}-03$

$[9] ,3.352317 \mathrm{e}-04 \quad 9.118659 \mathrm{e}-04 \quad 2.478705 \mathrm{e}-03$

$[10] ,1.233165 \mathrm{e}-04 \quad 3.354360 \mathrm{e}-04 \quad 9.118006 \mathrm{e}-04$

$$
[, 4] \quad[, 5] \quad[, 6]
$$

$[1] \quad ,4.969783 \mathrm{e}-02 \quad 1.829207 \mathrm{e}-02 \quad 6.730480 \mathrm{e}-03$

$[2] \quad ,1.353319 \mathrm{e}-01 \quad 4.978619 \mathrm{e}-02 \quad 1.831527 \mathrm{e}-02$

$[3] \quad ,3.678619 \mathrm{e}-01 \quad 1.353319 \mathrm{e}-01 \quad 4.978580 \mathrm{e}-02$

$[4] \quad ,1.000000 \mathrm{e}+00 \quad 3.678712 \mathrm{e}-01 \quad 1.353329 \mathrm{e}-01$

$[5] ,3.678712 \mathrm{e}-01 \quad 1.000000 \mathrm{e}+00 \quad 3.678598 \mathrm{e}-01$

$[6] \quad ,1.353329 \mathrm{e}-01 \quad 3.678598 \mathrm{e}-01 \quad 1.000000 \mathrm{e}+00$

$[7] \quad ,4.978635 \mathrm{e}-02 \quad 1.353309 \mathrm{e}-01 \quad 3.678703 \mathrm{e}-01$

$[8] ,1.831538 \mathrm{e}-02 \quad 4.978613 \mathrm{e}-02 \quad 1.353337 \mathrm{e}-01$

$[9] \quad ,6.737837 \mathrm{e}-03 \quad 1.831516 \mathrm{e}-02 \quad 4.978602 \mathrm{e}-02$

$[10] ,2.478512 \mathrm{e}-03 \quad 6.737119 \mathrm{e}-03 \quad 1.831260 \mathrm{e}-02$

\section{Gambar 4. Potongan Matriks S}

Langkah selanjutnya adalah menghitung matriks afinitas atau matriks simetris $\mathrm{W}$ berdasarkan matriks W. matriks $\mathrm{W}$ terdiri dari nilai positif dan simetris. Menghitung matriks W dengan menerapkan $k$ neighboor terdekat untuk membuat representasi grafik yang menghubungkan titik data terdekat menggunakan persamaan 2. Namun, menjadi simetris jika $w_{i j}$ dipilih sebagai tetangga terdekat begitu juga $w_{j i}$ sehingga diperoleh hasil pada Gambar 5. 


$$
\text { [,1] [,2] [, 3] [,4] }
$$

$\begin{array}{lllllllll}{[1,]} & 1.0000000 & 0.3659504 & 0.1349792 & 0.0000000\end{array}$

$[2] \quad 0.3659504 \quad 1.0000000 \quad 0.3678792 \quad$,

$\begin{array}{lllllll}{[3,]} & 0.1349792 & 0.3678792 & 1.0000000 & 0.3678619\end{array}$

$[4] \quad$,

$[5] \quad 0.0000000 \quad 0.0000000 \quad 0.0000000 \quad$,

$[6] \quad 0.0000000 \quad 0.00000000 .0000000 \quad$,

$[7] \quad 0.0000000 \quad$,

$[8] \quad 0.0000000 \quad 0.0000000 \quad$,

$[9] \quad 0.0000000 \quad 0.0000000 \quad 0.0000000 \quad$,

$[10] \quad 0.0000000 \quad$,

$$
[, 5] \quad[, 6] \quad[, 7] \quad[, 8]
$$

$[1] \quad 0.0000000 \quad 0.0000000 \quad 0.0000000 \quad$,

$[2] \quad 0.0000000 \quad 0.00000000 .0000000 \quad$,

$[3] \quad 0.0000000 \quad 0.0000000 \quad 0.0000000 \quad$,

$[4] \quad 0.36787120 .0000000 \quad 0.0000000 \quad$,

$[5,] \quad \begin{array}{llllll}1.0000000 & 0.3678598 & 0.0000000 & 0.0000000\end{array}$

$[6] \quad 0.3678598 \quad 1.00000000 .3678703 \quad$,

$\left[\begin{array}{lllllll}{[7,]} & 0.0000000 & 0.3678703 & 1.0000000 & 0.3678733\end{array}\right.$

$[8] \quad 0.0000000 \quad 0.0000000 \quad$,

$[9] \quad 0.0000000 \quad 0.0000000 \quad 0.0000000 \quad$,

$[10] \quad 0.0000000 \quad 0.0000000 \quad 0.0000000 \quad$,

\section{Gambar 5. Hasil Perhitungan Matriks W}

Dengan matriks similaritas clustering digantikan dengan partisi-grafik, komponen-komponen grafik yang terhubung diinterpretasikan sebagai cluster. Grafik harus dipartisi sehingga tepi yang menghubungkan cluster yang berbeda harus memiliki bobot yang rendah, dan tepi dalam cluster yang sama harus memiliki nilai yang tinggi dan dhitung menggunakan persamaan 4 maka diperoleh matriks $D$ seperti pada Gambar 6 .
[,1] [,2] [,3] [,4] [,5] $\left[\begin{array}{llllllllllll}{[1,]} & 1.50093 & 0.00000 & 0.00000 & 0.000000 & 0.000000\end{array}\right.$ $[2] \quad 0.000001 .73383 \quad 0.00000 \quad 0.000000 \quad$, $[3] \quad 0.00000 \quad 0.000001 .870720 .000000 \quad$, $[4] \quad 0.00000 \quad 0.00000 \quad 0.000001 .735733 \quad$, $[5] \quad 0.00000 \quad 0.00000 \quad 0.00000 \quad$, $[6] \quad 0.00000 \quad 0.00000 \quad 0.00000 \quad 0.000000 \quad$, $[7] \quad 0.00000 \quad 0.00000 \quad 0.00000 \quad 0.000000 \quad$, $\left[\begin{array}{llllllllllll} & 0.00000 & 0.00000 & 0.00000 & 0.000000 & 0.000000\end{array}\right.$ $[9] \quad 0.00000 \quad 0.00000 \quad 0.00000 \quad 0.000000 \quad$, $[10] \quad 0.000000 .00000 \quad$,

$$
[, 6] \quad[, 7] \quad[, 8] \quad[, 9] \quad[, 10]
$$

$[1] \quad 0.00000 \quad 0.000000 \quad 0.000000 \quad 0.000000 \quad$, $[2] \quad 0.00000 \quad 0.000000 \quad 0.000000 \quad 0.000000 \quad$, $[3] \quad 0.00000 \quad 0.000000 \quad 0.000000 \quad 0.000000 \quad$, $[4] \quad 0.00000 \quad 0.000000 \quad 0.000000 \quad 0.000000 \quad$, $[5] \quad 0.00000 \quad 0.000000 \quad 0.000000 \quad 0.000000 \quad$, $[6,] \quad \begin{array}{lllllll}1.73573 & 0.000000 & 0.000000 & 0.000000 & 0.000000\end{array}$ $[7] \quad 0.000001 .735744 \quad 0.000000 \quad 0.000000 \quad$, $\left[\begin{array}{llllllllll}{[8,]} & 0.00000 & 0.000000 & 1.735732 & 0.000000 & 0.000000\end{array}\right.$

$[9] \quad 0.00000 \quad 0.000000 \quad 0.0000001 .735498 \quad$, $\left[\begin{array}{llllllll}{[10,]} & 0.00000 & 0.000000 & 0.000000 & 0.000000 & 1.734877\end{array}\right.$ $[, 11] \quad[, 12] \quad[, 13] \quad[, 14] \quad[, 15]$

$[1] \quad 0.000000 \quad 0.000000 \quad 0.000000 \quad 0.000000 \quad$, $[2] \quad 0.000000 \quad 0.000000 \quad 0.000000 \quad 0.000000 \quad$, $[3] \quad 0.000000 \quad 0.000000 \quad 0.000000 \quad 0.000000 \quad$, $[4] \quad 0.000000 \quad 0.000000 \quad 0.000000 \quad 0.000000 \quad$, $[5] \quad 0.000000 \quad 0.000000 \quad 0.000000 \quad$, $[6] \quad 0.000000 \quad 0.000000 \quad 0.000000 \quad 0.000000 \quad$, $[7] \quad 0.000000 \quad 0.000000 \quad 0.0000000 .000000 \quad$, $[8] \quad 0.000000 \quad 0.000000 \quad 0.000000 \quad 0.000000 \quad$, $[9] \quad 0.000000 \quad 0.000000 \quad 0.000000 \quad$, $[10] \quad 0.0000000 .000000 \quad 0.000000 \quad 0.000000 \quad$,

\section{Gambar 6. Potongan Matriks Degree D}

Kemudian menghitung matriks Laplacian pada persamaan 3. Spectral clustering menghasilkan kelompok vertex sehingga barisan DNA MERS-CoV jarang berpindah dari satu cluster ke cluster lainnya.

$[, 1][, 2][, 3][, 4][, 5][, 6][, 7][, 8][, 9]$

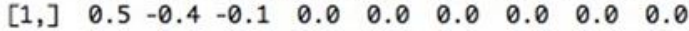
$\left[\begin{array}{llllllllll}{[2,]} & -0.4 & 0.7 & -0.4 & 0.0 & 0.0 & 0.0 & 0.0 & 0.0 & 0.0\end{array}\right.$ $\left[\begin{array}{llllllllll}{[3,]} & -0.1 & -0.4 & 0.9 & -0.4 & 0.0 & 0.0 & 0.0 & 0.0 & 0.0\end{array}\right.$ $\left[\begin{array}{llllllllll}{[4,]} & 0.0 & 0.0 & -0.4 & 0.7 & -0.4 & 0.0 & 0.0 & 0.0 & 0.0\end{array}\right.$ $\left[\begin{array}{llllllllll}{[5,]} & 0.0 & 0.0 & 0.0 & -0.4 & 0.7 & -0.4 & 0.0 & 0.0 & 0.0\end{array}\right.$

$\left[\begin{array}{llllllllll}{[6,]} & 0.0 & 0.0 & 0.0 & 0.0 & -0.4 & 0.7 & -0.4 & 0.0 & 0.0\end{array}\right.$

$\left[\begin{array}{llllllllll}{[7,]} & 0.0 & 0.0 & 0.0 & 0.0 & 0.0 & -0.4 & 0.7 & -0.4 & 0.0\end{array}\right.$

$\left[\begin{array}{llllllllll}{[8,]} & 0.0 & 0.0 & 0.0 & 0.0 & 0.0 & 0.0 & -0.4 & 0.7 & -0.4\end{array}\right.$

$\left[\begin{array}{llllllllll}{[9,]} & 0.0 & 0.0 & 0.0 & 0.0 & 0.0 & 0.0 & 0.0 & -0.4 & 0.7\end{array}\right.$

$\left[\begin{array}{llllllllll}10,] & 0.0 & 0.0 & 0.0 & 0.0 & 0.0 & 0.0 & 0.0 & 0.0 & -0.4\end{array}\right.$ $[, 10][, 11][, 12][, 13][, 14][, 15][, 16]$

$\left[\begin{array}{llllllll}{[1,]} & 0.0 & 0.0 & 0.0 & 0.0 & 0.0 & 0.0 & 0.0\end{array}\right.$

$\begin{array}{llllllll}{[2,]} & 0.0 & 0.0 & 0.0 & 0.0 & 0.0 & 0.0 & 0.0\end{array}$

$\left[\begin{array}{llllllll}{[3,]} & 0.0 & 0.0 & 0.0 & 0.0 & 0.0 & 0.0 & 0.0\end{array}\right.$

$\left[\begin{array}{llllllll}{[4,]} & 0.0 & 0.0 & 0.0 & 0.0 & 0.0 & 0.0 & 0.0\end{array}\right.$

$\begin{array}{llllllll}{[5,]} & 0.0 & 0.0 & 0.0 & 0.0 & 0.0 & 0.0 & 0.0\end{array}$

$\begin{array}{llllllll}{[6,]} & 0.0 & 0.0 & 0.0 & 0.0 & 0.0 & 0.0 & 0.0\end{array}$

$\begin{array}{llllllll}{[7,]} & 0.0 & 0.0 & 0.0 & 0.0 & 0.0 & 0.0 & 0.0\end{array}$

$\left[\begin{array}{llllllll}{[8,]} & 0.0 & 0.0 & 0.0 & 0.0 & 0.0 & 0.0 & 0.0\end{array}\right.$

$\begin{array}{llllllll}{[9,]} & -0.4 & 0.0 & 0.0 & 0.0 & 0.0 & 0.0 & 0.0\end{array}$

$\begin{array}{llllllll}{[10,]} & 0.7 & -0.4 & 0.0 & 0.0 & 0.0 & 0.0 & 0.0\end{array}$

Gambar 7. Potongan Matriks Laplacian 
Selanjutnya, dihasilkan 3 cluster, sehingga langkah selanjutnya adalah menemukan $k$ eigenvector terkecil dan diperoleh nilai $k$ eigenvector terkecil yaitu $-0,1005038$. Selanjutnya, normalisasi data dengan matriks $k$-eigen sehingga akan terbentuk $k=3$ kolom yang merepresentasikan setiap nilai normalisasi eigen pada setiap kolomnya. Hasil dari data normalisasi kemudian di cluster dengan menggunakan algoritma partisi $k$-means. Data normalisasi mewakili masukan data latih. Data latih ke$i$ akan dimasukkan pada suatu cluster jika dan hanya jika data hasil normalisasi ke$i$ masuk pada cluster yang sama. Sehingga hasil clustering dapat dilihat pada Tabel 1.

Tabel 1. Hasil Clustering 100 barisan DNA MERS-CoV

\begin{tabular}{clc}
\hline Cluster & \multicolumn{1}{c}{ Anggota } & Jumlah \\
\hline 1 & M28,M29,M30,M31,M32,M33,M34,M & 43 \\
& 35,M36,M37,M38,M39,M40,M41,M42, & \\
M43,M44,M45,M46,M47,M48,M49,M & \\
50,M51,M52,M53,M54,M55,M56,M57, & \\
M58,M59,M60,M61,M62,M63,M64,M & \\
& 65,M66,M67,M68,M69,M70 & \\
& & \\
& & \\
& M1,M2,M3,M4,M5,M6,M7,M8,M9,M1 & 28 \\
& 0,M11,M12,M13,M14,M15,M16,M17, & \\
& M18,M19,M20,M21,M22,M23,M24,M & \\
& 25,M26,M27,M100 & \\
3 & M71,M72,M73,M74,M75,M76,M77,M & 29 \\
& 78,M79,M80,M81,M82,M83,M84,M85, & \\
& M86,M87,M88,M89,M90,M91,M92,M & \\
& 93,M94,M95,M96,M97,M98,M99 & \\
&
\end{tabular}

Hasil clustering Tabel 1 menunjukkan bahwa cluster 1 memiliki anggota 43 barisan DNA MERS-CoV, cluster 2 memiliki 28 anggota barisan DNA MERS$\mathrm{CoV}$, dan cluster 3 memiliki 29 anggota barisan DNA MERS-CoV.

Untuk menganalisa lebih dalam lagi, dilakukan perbandingan dengan hasil clustering barisan DNA MERS-CoV dengan $k$-means tanpa mengunakan metode spectral clustering. Langkah yang dilakukan adalah mengubah data string menjadi numerik dengan $n$-mers frequency, normalisasi data menggunakan min-max normalization, kemudian barisan DNA MERS-CoV dilakukan clustering menggunakan k-means. Jumlah clustering optimal adalah 3 cluster. Perbandingan hasil clustering barisan DNA MERS-CoV dapat dilihat pada Tabel 2.

Tabel 2. Perbandingan Clustering dengan

K-Means saja dan Spectral Clustering dan K-Means

\begin{tabular}{ccccc}
\hline Metode & Cluster & $\begin{array}{c}\text { Jumlah } \\
\text { Anggota } \\
\text { Cluster }\end{array}$ & $\begin{array}{c}\text { withinss } \\
\text { clusters }\end{array}$ & $\begin{array}{c}\text { Total } \\
\text { sum of } \\
\text { square }\end{array}$ \\
\hline K-Means & 1 & 39 & $\mathbf{0 , 0 2 7 7 5 8 6 3}$ & \\
& 2 & 16 & $\mathbf{0 , 0 0 2 0 6 6 6 1 9}$ & $\begin{array}{c}\mathbf{0 , 3 0 1 9 8} \\
\mathbf{5 8}\end{array}$ \\
SC-K- & 3 & 45 & $\mathbf{0 , 0 2 8 2 4 5 7 4}$ & \\
Means & 1 & 43 & $\mathbf{0 , 1 6 5 3 9 5 8 8}$ & \\
& 2 & 28 & $\mathbf{0 , 0 8 6 1 5 0 1 2}$ & $\mathbf{1 , 9 9 9 3 6}$ \\
& 3 & 29 & $\mathbf{0 , 0 9 4 6 8 9 8 7}$ & 2 \\
\hline
\end{tabular}

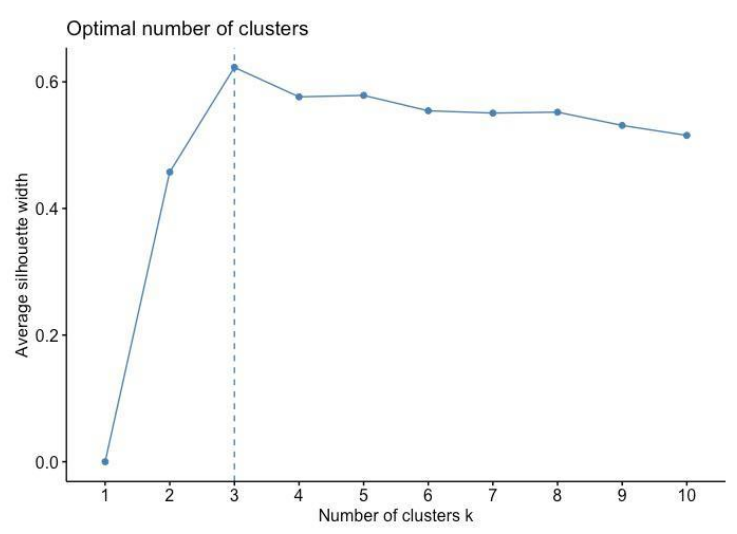

Gambar 8. Hasil rata-rata Sillhouette Metode Spectral clustering dan Algoritma K-Means 


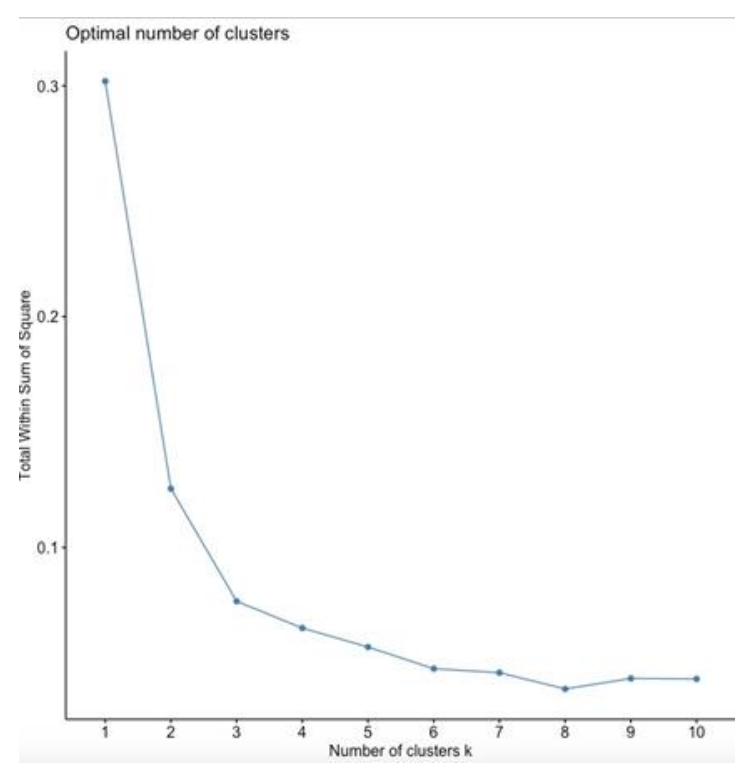

Gambar 9. Hasil rata-rata Sillhouette Metode K-Means

Tabel 2 menunjukkan perbedaan nilai withnss clusters pada k-means lebih rendah dibandingkan dengan spectral clustering dan $k$-means artinya pengukuran jarak ratarata kuadrat dari semua titik pada pusat cluster pada spectral clustering dengan $k$ means masih lebih baik dibandingkan dengan clustering dengan $k$-means saja. Total sum of square metode $k$-means lebih rendah dibandingkan dengan spectral clustering dan k-means artimya penyebaran variable yang diamati pada sekitar means pada spectral clustering dan $k$-means masih lebih baik dibandingkan dengan clustering dengan $k$-means saja. Dengan kata lain, kemiripan barisan DNA dalam clustering dengan metode spectral clustering dan k-means masih lebih baik dibandingkan clustering hanya dengan $k$ means saja. Sehingga, clustering menggunakan metode spectral clustering dan algoritma $k$-means memberikan hasil clustering yang lebih homogen dibandingkan dengan clustering k-means tanpa menggunakan spectral clustering.

\section{SIMPULAN}

Pada penelitian ini, barisan DNA MERS$\mathrm{CoV}$ dapat di clustering menggunakan metode spectral clustering dan algoritma $k$-means. Langkah-langkah yang dilakukan pada penelitian ini adalah megubah data menjadi numerik, kemudian dilakukan normalisasi data, clustering barisan DNA menggunakan metode spectral clustering dengan tahapan mengkonstruksi graf similartitas, kemudian menghitung matriks normalisasi Laplacian, hitung k-eigen value, serta hasil dari data normalisasi kemudian di cluster dengan menggunakan algoritma partisi $k$-means. Hasil penelitian menunjukkan bahwa hasil clustering dengan metode spectral clustering dan algoritma $k$-means dihasilakan tiga cluster dan lebih homogen dibandingkan dengan clustering hanya menggunakan $k$-means saja.

\section{DAFTAR PUSTAKA}

[1] N. H. Rampengan, "Middle East Respiratory Syndrome," $J$. Biomedik, vol. 8, no. 1, pp. 17-26, 2016.

[2] World Health Organization, "Mers Situation Update November 2019," 2019.

[3] S. Nur'aini, A. S. Mukaromah, and S. Muhlisoh, "Pengenalan Deoxyribonucleic Acid (DNA) Dengan Marker-Based Augmented Reality," Walisongo J. Inf. Technol., vol. 1, no. 2, p. 91, 2019, doi: 10.21580/wjit.2019.1.2.4531.

[4] A. Bustamam, E. D. Ulul, H. F. A. Hura, and T. Siswantining, "Implementation of hierarchical clustering using k-mer sparse matrix to analyze MERS-CoV genetic relationship," AIP Conf. Proc., vol. 1862, no. July, 2017, doi: 10.1063/1.4991246. 
[5] S. Ren, S. Zhang, and T. Wu, "An Improved Spectral Clustering Community Detection Algorithm Based on Probability Matrix," Discret. Dyn. Nat. Soc., vol. 2020, 2020, doi: 10.1155/2020/4540302.

[6] A. Yusuf and H. Tjandrasa, "Prediksi Nilai Dengan Metode Spectral Clustering Dan Clusterwise Regression," J. Simatec, vol. VIII, no. 1, pp. 39-45, 2013.

[7] A. J. Chin, A. Mirzal, and H. Haron, "Spectral clustering on gene expression profile to identify cancer types or subtypes," J. Teknol., vol. 76, no. 1, pp. 289-297, 2015, doi: 10.11113/jt.v76.4036.

[8] M. Nafis Ul Alam and U. F. Chowdhury, "Short k-mer abundance profiles yield robust machine learning features and accurate classifiers for RNA viruses," PLoS One, vol. 15, no. 9 September, pp. 1-23, 2020, doi: 10.1371/journal.pone.0239381.

[9] S. Deorowicz, M. Kokot, S. Grabowski, and A. DebudajGrabysz, "KMC 2: Fast and resource-frugal k-mer counting," Bioinformatics, vol. 31 , no. 10, pp. 1569-1576, 2015, doi: 10.1093/bioinformatics/btv022.

[10] D. F. Pramesti, Lahan, M. Tanzil Furqon, and C. Dewi, "Implementasi Metode K-Medoids Clustering Untuk Pengelompokan Data," J. Pengemb. Teknol. Inf. dan Ilmu Komput., vol. 1, no. 9, pp. 723-732, 2017, doi: 10.1109/EUMC.2008.4751704. 